\title{
Thermal Utilization and Heat Use Efficiency of Green Gram Varieties under Different Sowing Dates
}

\author{
D.S. Bankar ${ }^{1}$, S.B. Pawar ${ }^{2}$ and Y.E. Kadam ${ }^{*}$ \\ ${ }^{I}$ Department of Agriculture Meteorology, VNMKV, Parbhani, Maharashtra, India \\ ${ }^{2}$ NARP, Aurangabad, India \\ *Corresponding author
}

\begin{tabular}{|l|}
\hline K e y w o r d s \\
Green gram, \\
Varieties, GDD, \\
HTU, PTU, HUE \\
and HTUE
\end{tabular}

\section{Introduction}

Green gram (Vigna radiata L. Wilczek) is one of the most important pulse crops of global economic importance. It is locally called as moong or mug and belongs to the family Leguminoceae, it fixes atmospheric nitrogen and improves soil fertility by adding $20-25 \mathrm{~kg}$ $\mathrm{N} \mathrm{ha}^{-1}$ (Md Tariqul Islam, 2015). Mung bean has originated in India and is a native of India and central Asia. It is grown in these areas since prehistoric period. Mung bean is grown throughout Southern Asia including India, Pakistan, Bangladesh, Srilanka, China etc. In India green gram is mostly grown in Andhra Pradesh, Maharashtra, Orissa, Rajasthan, Gujarat, Madhya Pradesh, Punjab and Uttar Pradesh etc. 
Temperature is one of the primary microclimatic factors driving rates of growth. Rate of plant growth and development is dependent upon temperature surrounding the plant and each species has a specific temperature range represented by a minimum, maximum, and optimum. These values were summarized by Hatfield et al., (2011) for a number of different species typical of grain and fruit production. The number of days required for cultivars to reach maturity depends primarily on location, date of planting and temperature. Due to variations in daily minimum and maximum temperatures from year to year and between location, number of days from planting to physiological maturity varies and, is not a good predictor of crop development.

Meteorological indices viz. growing degree days (GDD), helio-thermal unit (HTU), and photo-thermal unit (PTU) based on air temperature are used to describe changes in phenological behavior and growth parameters (Paul et al., 2000; Girijesh et al., 2011; Prakash et al., 2015). The temperature based agrometeorological indices provide a reliable prediction for crop development and yield.

Influence of temperature on phenology and yield of crops can be studied under the field condition through accumulated heat unit system (Pandey et al., 2010). Duration of crop/cultivars is a genetic attributes, and is influenced by environmental condition, which varies with location and years in which it is grown because the rate of development is largely influenced by the temperature and photoperiod. Plants have a definite heat requirement before they attain certain phenophases. A change in temperature during phenophases of a crop adversely affects the initiation and duration of different phenophases and finally the economic yield. It is therefore, indispensable to have knowledge of the exact duration of phenophases in a particular environment and their association with yield attributes for achieving the higher yield, hence keeping above in view the present investigation was carried out.

\section{Materials and Methods}

An experiment was conducted on experimental farm at Department of Agril. Meteorology, College of Agriculture, Vasantrao Naik Marathwada Krishi Vidyapeeth, Parbhani, during Kharif season 2017, Parbhani $\left(19^{0} 16^{\prime}\right.$ North latitude and $76^{0}$ 47' East longitude and at an altitude of 409 meter above mean sea level (MSL)). The treatments comprised of four dates of sowing viz. $\mathrm{D}_{1}\left(24^{\text {th }} \mathrm{MW}\right), \mathrm{D}_{2}\left(26^{\text {th }} \mathrm{MW}\right), \mathrm{D}_{3}\left(28^{\text {th }}\right.$ $\mathrm{MW})$ and $\mathrm{D}_{4}\left(30^{\text {th }} \mathrm{MW}\right)$ with four varieties in sub plot viz. Vaibhav, BM-4, BM-2002-1 and BM-2003-2 in sub plot were replicated thrice in a split plot design. All cultural operations and plant protection measures were followed as per the recommendations contained in package of practices. Meteorological data were recorded from Agrometeorological Observatory, Department of Agricultural meteorology college of Agriculture, VNMKV, Parbhani. The grain, straw and biological yields were recorded as per treatments and expressed in $\mathrm{kg} \mathrm{ha}^{-1}$. Growing degree days (GDD), helio thermal units (HTU), photo thermal units (PTU), heat use efficiency (HUE), and helio thermal use efficiency were computed using the daily meteorological data. The base temperature of $10{ }^{\circ} \mathrm{C}$ was used for computation of GDD on daily basis (Leong and Ong, 1983). Agro-meteorological indices were computed for different phenophases of crop (emergence, Bud emergence, Flower emergence, Pod emergence and Harvest) by adopting. Data were analyzed with analysis of variance (ANOVA) as standard method. Treatments were compared by computing the F-test. The significant differences between treatments were compared pare wise by critical difference at the 5 per cent level of probability. 


\section{Results and Discussion}

\section{Phenology}

In general attributes of green gram varieties were markedly influenced with sowing dates (Table 1). The $\mathrm{D}_{2}\left(26^{\text {th }} \mathrm{MW}\right)$ sown crop significantly required to more number of days required for 50 per cent flowering (40 days) and followed by $\mathrm{D}_{1}\left(24^{\text {th }} \mathrm{MW}\right)$ (38 days), $\mathrm{D}_{4}$ (30 $\left.{ }^{\text {th }} \mathrm{MW}\right)$ (37 days) and $\mathrm{D}_{3}\left(28^{\text {th }} \mathrm{MW}\right)(35$ days) and varieties $\mathrm{V}_{1}$ (Vaibhav) (39 days) followed by (BM-2002-1), (BM-2003-2) and (BM-4) however same trend was recorded in case of days to maturity. This might be due to the fact that sowing time determines time available for vegetative phase before onset of flowering, which is mainly influenced by the photoperiod.

Days to 50 per cent flowering and days to maturity differed significantly among the green gram varieties and same trend was followed in days to maturity, whereas the $\mathrm{D}_{1}$ ( $\left.24^{\text {th }} \mathrm{MW}\right)$ (71 days) more days required to maturity as compare to rest of sowing date and varieties $\mathrm{V}_{1}$ (Vaibhav) (74 days) followed by (BM-2003-2), (BM-2002-1) and (BM-4). The variation in phenology of green gram varieties was also reported by Taleei et al., (1999).

\section{Yield attributes}

The yield parameters of green gram varieties markedly influenced with sowing dates (Table 1). Grain and straw yields of green gram variety were significantly higher with $\mathrm{D}_{1}\left(24^{\text {th }}\right.$ MW) sown crop (970 Kg ha ${ }^{-1}$ ) and respective increase was 6.6 per cent, 51.1 per cent and 130 per cent over $\mathrm{D}_{2}\left(26^{\text {th }} \mathrm{MW}\right), \mathrm{D}_{3}\left(28^{\text {th }} \mathrm{MW}\right)$ and $\mathrm{D}_{4}\left(30^{\text {th }} \mathrm{MW}\right)$ respectively. Higher seed yield was realized in case of $\mathrm{D}_{1}\left(24^{\text {th }} \mathrm{MW}\right)$ sown crop because of higher growth and yield attributed which lead to higher yield of the respective treatments. Grain and straw yield differed significantly among the green gram varieties. The green gram varieties (BM-20032) recorded significantly higher grain yield $\left(819 \mathrm{Kg} \mathrm{ha}^{-1}\right)$ followed by (BM-2002-1) (753 $\left.\mathrm{Kg} \mathrm{ha}^{-1}\right)$ and the lowest with (BM-4) $(666 \mathrm{~kg}$ $\mathrm{ha}^{-1}$ ).

However Straw and biological yield significantly highest in $\mathrm{D}_{1}\left(24^{\mathrm{th}} \mathrm{MW}\right)$ and (BM-2003-2) as compare to rest of treatments. This might be due to more growth attributes like more plant population, no of green leaves, dry matter and leaf area was recorded more with the respective treatments Taleei et al., (1999).

\section{Heat use efficiency and helio thermal use efficiency}

At maturity, HUE for grain and straw production was significantly higher $(0.52$ and $1.10 \mathrm{~kg} / \mathrm{ha}{ }^{0} \mathrm{C}$ day) for $\mathrm{D}_{1}\left(24^{\text {th }} \mathrm{MW}\right)$ sown crop as compared to rest of sowing dates sown crop (Table 2). Among varieties, (BM-2003-2) had significantly higher heat use efficiency $\left(0.44 \mathrm{~kg} / \mathrm{ha}{ }^{0} \mathrm{C}\right.$ day) followed by BM-2002-1 (0.41 kg/ha ${ }^{0} \mathrm{C}$ day), BM-4 (0.39 kg/ha ${ }^{0} \mathrm{C}$ day) and Vaibhav $\left(0.35 \mathrm{~kg} / \mathrm{ha}{ }^{0} \mathrm{C}\right.$ day) for grain production, whereas, same trend was followed in straw and biological yield. Helio thermal use efficiency for grain and straw was found maximum 0.10 and 0.21 , respectively for $\mathrm{D}_{1}\left(24^{\text {th }} \mathrm{MW}\right)$ sown crops. In case of varieties, BM-2003-2 had highest heliothermal use efficiency 0.09 and 0.19 , respectively for grain and straw production.

The minimum helio thermal use efficiency was found in Vaibhav for grain as well as straw production. Higher HUE and HTUE in timely sown could be attributed to the highest grain and straw yield. As the temperature was optimum throughout growing period crop utilized heat more efficiently and increased biological activity that confirm higher yield. Similar relationship was expressed by Thavaprakash et al., (2007). 
Table.1 Yield and yield attributes of green gram varieties under different thermal environments

\begin{tabular}{|c|c|c|c|c|c|}
\hline Treatment & $\begin{array}{c}\text { Days to } \\
\mathbf{5 0 \%} \\
\text { flowering }\end{array}$ & $\begin{array}{l}\text { Days to } \\
\text { Maturity }\end{array}$ & $\begin{array}{c}\text { Seed } \\
\text { yield (kg } \\
\left.\mathrm{ha}^{-1}\right)\end{array}$ & $\begin{array}{c}\text { Straw } \\
\text { yield (kg } \\
\left.\text { ha }^{-1}\right)\end{array}$ & $\begin{array}{c}\text { Biological } \\
\text { yield } \\
\left(\mathrm{kg} \mathrm{ha}^{-1}\right)\end{array}$ \\
\hline \multicolumn{6}{|c|}{ Sowing dates (D) } \\
\hline $\mathrm{D}_{1}$ (MW 24) & 38.0 & 71.0 & 970 & 2060 & 3030 \\
\hline $\mathrm{D}_{2}$ (MW 26) & 40.0 & 69.0 & 910 & 1949 & 2859 \\
\hline $\mathrm{D}_{3}$ (MW 28) & 35.0 & 69.0 & 642 & 1529 & 2171 \\
\hline $\mathrm{D}_{4}(\mathrm{MW} 30)$ & 37.0 & 66.0 & 421 & 1088 & 1508 \\
\hline $\mathrm{SE} \pm$ & 0.62 & 0.57 & 22.74 & 50.06 & 69.61 \\
\hline CD at $5 \%$ & 1.82 & 1.69 & 78.69 & 173.25 & 240.90 \\
\hline \multicolumn{6}{|c|}{ Varieties (V) } \\
\hline $\mathrm{V}_{1}$ (Vaibhav) & 39.0 & 74.0 & 703 & 1625 & 2322 \\
\hline $\mathrm{V}_{2}(\mathrm{BM}-4)$ & 36.0 & 65.0 & 666 & 1596 & 2270 \\
\hline $\mathrm{V}_{3}(\mathrm{BM}-2002-1)$ & 37.5 & 67.0 & 753 & 1652 & 2391 \\
\hline $\mathrm{V}_{4}$ (BM-2003-2) & 37.5 & 69.0 & 819 & 1753 & 2585 \\
\hline $\mathrm{SE} \pm$ & 0.75 & 0.64 & 18.19 & 41.87 & 61.05 \\
\hline CD at $5 \%$ & 2.19 & 1.97 & 54.55 & 125.53 & 183.03 \\
\hline \multicolumn{6}{|c|}{ Interaction (D X V) } \\
\hline $\mathrm{SE} \pm$ & 1.50 & 1.21 & 47.96 & 64.49 & 167.03 \\
\hline CD at $5 \%$ & NS & $\mathrm{NS}$ & NS & NS & NS \\
\hline Mean & 37.50 & 68.8 & 736 & 1656 & 2392 \\
\hline
\end{tabular}

Table.2 Heat use efficiency (HUE) and Helio thermal use efficiency (HTUE) of different

\begin{tabular}{|c|c|c|c|c|c|c|}
\hline \multirow[t]{2}{*}{ Treatment } & \multicolumn{3}{|c|}{ HUE (Kg ha ${ }^{-1}{ }^{0} \mathrm{C}$ day) } & \multicolumn{3}{|c|}{ HTUE (Kg ha ${ }^{-10} \mathrm{C}$ day) } \\
\hline & $\begin{array}{l}\text { Seed } \\
\text { Yield }\end{array}$ & $\begin{array}{c}\text { Straw } \\
\text { Yield }\end{array}$ & $\begin{array}{c}\text { Biological } \\
\text { Yield }\end{array}$ & $\begin{array}{l}\text { Seed } \\
\text { Yield }\end{array}$ & $\begin{array}{c}\text { Straw } \\
\text { Yield }\end{array}$ & $\begin{array}{c}\text { Biological } \\
\text { Yield }\end{array}$ \\
\hline \multicolumn{7}{|c|}{ Dates of sowing } \\
\hline $\mathrm{D}_{1}$ (MW 24) & 0.52 & 1.10 & 1.62 & 0.10 & 0.21 & 0.32 \\
\hline$\overline{D_{2}(M W ~ 26)}$ & 0.50 & 1.07 & 1.57 & 0.10 & 0.22 & 0.33 \\
\hline $\mathrm{D}_{3}$ (MW 28) & 0.37 & 0.87 & 1.24 & 0.08 & 0.18 & 0.26 \\
\hline $\mathrm{D}_{4}(\mathrm{MW} 30)$ & 0.24 & 0.63 & 0.87 & 0.04 & 0.11 & 0.15 \\
\hline \multicolumn{7}{|c|}{ Varieties } \\
\hline$\overline{V_{1} \text { (Vaibhav) }}$ & 0.35 & 0.82 & 1.17 & 0.07 & 0.16 & 0.23 \\
\hline$\overline{V_{2}(B M-4)}$ & 0.39 & 0.93 & 1.33 & 0.08 & 0.19 & 0.26 \\
\hline$V_{3}(B M-2002-1)$ & 0.41 & 0.91 & 1.31 & 0.08 & 0.18 & 0.26 \\
\hline $\mathrm{V}_{4}(\mathrm{BM}-2003-2)$ & 0.44 & 0.95 & 1.40 & 0.09 & 0.19 & 0.28 \\
\hline
\end{tabular}


Table.3 Phenophase wise Agrometeorological indices required as influenced by various treatments of green gram during Kharif season sowing dates and Varieties

\begin{tabular}{|c|c|c|c|c|c|c|}
\hline \multirow[t]{2}{*}{ Treatments } & \multicolumn{6}{|c|}{ Photo thermal index } \\
\hline & $\mathbf{P}_{1}$ & $\mathbf{P}_{2}$ & $\mathbf{P}_{3}$ & $\mathbf{P}_{4}$ & $\mathbf{P}_{5}$ & Total \\
\hline \multicolumn{7}{|c|}{ Dates of sowing } \\
\hline $\mathrm{D}_{1}$ (MW 24) & 28.0 & 28.0 & 25.6 & 25.8 & 26.5 & 26.8 \\
\hline $\mathrm{D}_{2}$ (MW 26) & 27.6 & 26.1 & 26.8 & 25.9 & 25.9 & 26.3 \\
\hline $\mathrm{D}_{3}$ (MW 28) & 24.6 & 26.7 & 26.5 & 23.8 & 26.5 & 26.1 \\
\hline $\mathrm{D}_{4}$ (MW 30) & 26.4 & 26.3 & 25.1 & 25.6 & 27.0 & 26.3 \\
\hline \multicolumn{7}{|c|}{ Varieties } \\
\hline $\mathrm{V}_{1}$ (Vaibhav) & 26.9 & 26.8 & 26.2 & 25.6 & 26.5 & 26.4 \\
\hline $\mathrm{V}_{2}(\mathrm{BM}-4)$ & 26.6 & 26.7 & 25.9 & 25.3 & 26.5 & 26.3 \\
\hline $\mathrm{V}_{3}(\mathrm{BM}-2002-1)$ & 26.4 & 26.8 & 26.1 & 25.1 & 26.5 & 26.4 \\
\hline $\mathrm{V}_{4}(\mathrm{BM}-2003-2)$ & 26.8 & 26.8 & 26.0 & 25.5 & 26.4 & 26.4 \\
\hline \multicolumn{7}{|c|}{ Growing degree days ( ${ }^{0} \mathrm{C}$ days) } \\
\hline \multicolumn{7}{|c|}{ Dates of sowing } \\
\hline $\mathrm{D}_{1}(\mathrm{MW} 24)$ & 195.8 & 476.2 & 281.5 & 206.0 & 714.9 & 1874.5 \\
\hline $\mathrm{D}_{2}(\mathrm{MW} 26)$ & 304.1 & 469.7 & 241.6 & 155.3 & 647.5 & 1818.1 \\
\hline $\mathrm{D}_{3}$ (MW 28) & 147.8 & 400.3 & 291.4 & 166.4 & 741.8 & 1747.7 \\
\hline $\mathrm{D}_{4}$ (MW 30) & 184.9 & 421.2 & 300.8 & 153.8 & 673.8 & 1734.5 \\
\hline \multicolumn{7}{|c|}{ Varieties } \\
\hline$V_{1}$ (Vaibhav) & 242.2 & 455.5 & 340.2 & 230.8 & 714.7 & 1983.4 \\
\hline $\mathrm{V}_{2}(\mathrm{BM}-4)$ & 186.2 & 400.8 & 259.4 & 177.3 & 687.8 & 1711.5 \\
\hline $\mathrm{V}_{3}(\mathrm{BM}-2002-1)$ & 158.2 & 428.2 & 313.2 & 150.6 & 768.4 & 1818.5 \\
\hline $\mathrm{V}_{4}(\mathrm{BM}-2003-2)$ & 214.2 & 482.9 & 286.3 & 204.1 & 661.0 & 1848.5 \\
\hline \multicolumn{7}{|c|}{ Helio thermal unit ( ${ }^{0} \mathrm{C}$ day hours) } \\
\hline \multicolumn{7}{|c|}{ Dates of sowing } \\
\hline$\overline{D_{1}(\mathrm{MW} 24)}$ & 1585.9 & 3095.3 & 534.9 & 947.6 & 3431.8 & 9595.5 \\
\hline $\mathrm{D}_{2}$ (MW 26) & 1976.3 & 1221.2 & 1811.6 & 450.4 & 3302.3 & 8761.8 \\
\hline $\mathrm{D}_{3}$ (MW 28) & 236.5 & 2321.5 & 1282.2 & 349.4 & 4228.3 & 8417.8 \\
\hline $\mathrm{D}_{4}$ (MW 30) & 1331.6 & 1642.7 & 1233.3 & 1338.1 & 4244.6 & 9790.3 \\
\hline \multicolumn{7}{|c|}{ Varieties } \\
\hline$V_{1}$ (Vaibhav) & 1356.5 & 2141.0 & 1530.7 & 1061.8 & 3859.3 & 9949.2 \\
\hline $\mathrm{V}_{2}(\mathrm{BM}-4)$ & 1042.6 & 1883.6 & 1167.1 & 815.7 & 3714.3 & 8623.3 \\
\hline$V_{3}(B M-2002-1)$ & 885.6 & 2012.4 & 1409.5 & 692.6 & 4149.1 & 9149.2 \\
\hline $\mathrm{V}_{4}(\mathrm{BM}-2003-2)$ & 1199.5 & 2269.8 & 1288.3 & 938.8 & 3569.4 & 9265.8 \\
\hline \multicolumn{7}{|c|}{ Photo thermal unit ( ${ }^{0} \mathrm{C}$ day hours) } \\
\hline \multicolumn{7}{|c|}{ Dates of sowing } \\
\hline $\mathrm{D}_{1}(\mathrm{MW} 24)$ & 2590.4 & 6295.4 & 3710.2 & 2702.7 & 9251.45 & 24550.13 \\
\hline $\mathrm{D}_{2}(\mathrm{MW} 26)$ & 4016.5 & 6176.6 & 3285.1 & 1994.1 & 8054.90 & 23527.08 \\
\hline $\mathrm{D}_{3}$ (MW 28) & 1946.5 & 5347.3 & 3767.8 & 2083.3 & 9146.39 & 22291.37 \\
\hline $\mathrm{D}_{4}$ (MW 30) & 2519.0 & 5391.4 & 3741.9 & 1897.9 & 8293.86 & 21844.08 \\
\hline \multicolumn{7}{|c|}{ Varieties } \\
\hline$V_{1}$ (Vaibhav) & 3221.7 & 5981.2 & 4432.2 & 2931.7 & 8933.5 & 25500.2 \\
\hline $\mathrm{V}_{2}(\mathrm{BM}-4)$ & 2476.2 & 5262.1 & 3379.3 & 2251.9 & 8598.0 & 21967.6 \\
\hline $\mathrm{V}_{3}(\mathrm{BM}-2002-1)$ & 2103.4 & 5621.7 & 4081.3 & 1912.1 & 9604.5 & 23322.9 \\
\hline $\mathrm{V}_{4}(\mathrm{BM}-2003-2)$ & 2848.9 & 6340.9 & 3730.4 & 2591.8 & 8262.5 & 23774.4 \\
\hline
\end{tabular}

$\mathrm{P}_{1}$ : Sowing to Germination; $\mathrm{P}_{2}$ : Germination to Bud emergence; $\mathrm{P}_{3}$ : Bud emergence to Flower emergence; $\mathrm{P}_{4}$ : Flower emergence to Pod emergence; $\mathrm{P}_{5}$ : Pod emergence to Harvest 


\section{Agrometeorological indices}

The agrometeorological indices (GDD, HTU, PTI and PTU) during different phenophases of green gram are presented in (Table 3). The $\mathrm{D}_{1}\left(24^{\text {th }} \mathrm{MW}\right)$ sown crop took longer duration for maturity and crop took more days to fulfill the thermal requirement than the rest of sowing dates. Photo thermal index was highest for $\mathrm{D}_{1}\left(24^{\text {th }} \mathrm{MW}\right)$ sown crops at all the phenophases (Table 1), the total PTI value of which was significantly higher $\left(26.8^{\circ} \mathrm{C}\right)$ in $\mathrm{D}_{1}$ $\left(24^{\text {th }} \mathrm{MW}\right)$ sown crop followed by $\mathrm{D}_{2}\left(26^{\text {th }}\right.$ $\mathrm{MW}), \mathrm{D}_{4}\left(30^{\text {th }} \mathrm{MW}\right)$ and $\mathrm{D}_{3}\left(28^{\text {th }} \mathrm{MW}\right)$ respectively and PTI values was not more difference in among the varieties.

The total accumulated GDD and PTU during the maximum reproductive stage of the crop decreased from $673.8{ }^{\circ} \mathrm{C}$ days and $8293.9{ }^{\circ} \mathrm{C}$ days' $h r$ under $\mathrm{D}_{4}\left(30^{\text {th }} \mathrm{MW}\right)$ sowing to 714.9 ${ }^{\circ} \mathrm{C}$ days and $9251.5^{\circ} \mathrm{C}$ days' $\mathrm{hr}$ under timely sowing on $\mathrm{D}_{1}\left(24^{\text {th }} \mathrm{MW}\right)$, respectively. $\mathrm{D}_{1}$ $\left(24^{\text {th }} \mathrm{MW}\right)$ sown crop accumulated more heat unit $\left(1874.5^{\circ} \mathrm{C}\right.$ days) to reach maturity followed by $\mathrm{D}_{2}\left(26^{\text {th }} \mathrm{MW}\right)\left(1818.1^{\circ} \mathrm{C}\right.$ days $)$, $\mathrm{D}_{3}\left(28^{\text {th }} \mathrm{MW}\right)\left(1747.7^{\circ} \mathrm{C}\right.$ days $)$ and $\mathrm{D}_{4}\left(30^{\text {th }}\right.$ MW) $\left(1734.5{ }^{\circ} \mathrm{C}\right.$ days).one month delay in sowing from $\mathrm{D}_{1}\left(24^{\text {th }} \mathrm{MW}\right)$ (early sown) to $\mathrm{D}_{4}$ $\left(30^{\text {th }}\right.$ MW) (delay sown) increased the accumulated heat units and photo-thermal units by $140{ }^{\circ} \mathrm{C}$ days and $2706{ }^{\circ} \mathrm{C}$ days' hr, respectively. Among the varieties, Vaibhav had higher heat units $\left(1983.4{ }^{\circ} \mathrm{C}\right.$ days) and photo-thermal units $\left(25500.2{ }^{\circ} \mathrm{C}\right.$ days $\left.\mathrm{hr}\right)$, which might be due to significantly higher number of days taken to maturity lowest by BM-4 $\left(1711.5{ }^{\circ} \mathrm{C}\right.$ days and $21967.6{ }^{\circ} \mathrm{C}$ days hr). This might be due to better growing conditions such as temperature, light, humidity and rainfall to fully exploit genetic potentiality of crop (Bahar et al., 2015).

The total accumulated HTU during the maximum reproductive stage of the crop increase from $3431.8{ }^{\circ} \mathrm{C}$ days' $\mathrm{hr}$ under $\mathrm{D}_{1}$
( $24^{\text {th }} \mathrm{MW}$ ) sowing to $4244.6{ }^{\circ} \mathrm{C}$ days' $\mathrm{hr}$ under delay sowing on, $\mathrm{D}_{4}\left(30^{\text {th }} \mathrm{MW}\right)$ respectively. $\mathrm{D}_{4} \quad\left(30^{\text {th }} \quad \mathrm{MW}\right)$ sown crop accumulated more HTU $\left(9790.3{ }^{\circ} \mathrm{C}\right.$ days hours) to reach maturity followed by $\mathrm{D}_{1}\left(24^{\text {th }}\right.$ MW) $\left(9595.5{ }^{\circ} \mathrm{C}\right.$ days hours, $) \mathrm{D}_{2}\left(26^{\text {th }} \mathrm{MW}\right)$ $\left(8761.8{ }^{\circ} \mathrm{C}\right.$ days hours $)$ and $\mathrm{D}_{3}\left(28^{\text {th }} \mathrm{MW}\right)$ $\left(8417.8{ }^{\circ} \mathrm{C}\right.$ days) respectively. Among the varieties, Vaibhav had higher HTU (9949.2 ${ }^{\circ} \mathrm{C}$ days hours) and followed by BM-2003-2, BM-2002-1 and BM-4 respectively.

Based on the above findings, it may be concluded that $\mathrm{D}_{1}\left(24^{\text {th }} \mathrm{MW}\right)$ produced higher grain yield $(970 \mathrm{~kg} / \mathrm{ha})$ as compare to other sowing dates however among varieties BM2003-2 produced higher grain yield (819 $\mathrm{kg} / \mathrm{ha}$ ) followed by BM-2002-1, Vaibhav and BM-4 respectively. On an average, timely sown variety produced the maximum grain. The variety BM-2003-2 showed stable yield in almost both the sowing dates and performing overall best in terms of utilization of HUE and HTUE. The growing degree day, photo-thermal unit and photo-thermal index for entire crop growing period decreased with delayed sowing. This study also indicated that change in microclimate due to different sowing time is reflected in individual phonological stage. Differences in agrometeorological indices for various phonological stages indicated that accumulated temperature can be utilized for dry biomass and crop yield forecast.

\section{References}

Bahar, A.H., Adam, K.I. and Ali, S.A.M. (2015). Effect of variety and sowing date on performance of rain-fed sorghum (Sorghum bicolor L.) grown at Zalingei Locality in Darfur, Sudan. J. Agric. Sci. Eng., 1(1): 22-27.

Girijesh, G.K., Kumarswamy, A.S., Sreedhar, S., Kumar, M.D., Vageesh, T.S. and Rajashekarappa, K.S. (2011). Heat unit 
utilization of kharif maize in transitional zone of Karnataka. J. Agrometeorology., 13(1):43-45.

Hatfield, J.L., Boote, K.J., Kimball, B.A., Ziska, L.H., Izaurralde, R.C., Ort, D., Thomson, A.M., Wolfe, D.W. (2011). Climate impacts on agriculture: implications for crop production. Agron. J., 103:351-370.

Leong, S.K. and Ong, C.K. (1983). The influence of temperature and soil waster deficit on the development and morphology of groundnut (Arachis hypogaea L.). J. Exp. Botany., 34: 15511561.

Md Tariqul Islam (2015). Effects of high temperature on photosynthesis and yield in mungbean. Bangladesh J. Bot., 44(3): 451-454.

Pandey, I.B., Pandey, R.K., Dwivedi, D.K. and Singh, R.S. (2010). Phenology, heat unit requirement and yield of wheat (Triticum aestivum) variety under different crop growing environment. Ind. J. Agric. Sci., 80(2):136-140.
Paul, N.K. and Sarkar, D.K. (2000). Accumulated heat units and phenology relationship in wheat as influenced by sowing dates. Bangladesh J. Botany., 29:49-54.

Prakash, V., Niwas Ram, Khichar, M.L., Sharma Dinesh, Manmohan and Singh Baljeet (2015). Agrometeorological indices and intercepted photosynthetically active radiation in cotton crop under different growing environments. J. Cotton Res. Dev., 29(2): 268-272.

Taleei A. R., N. Khoda-Bandeh and B. Gholamie (1999). Effects of sowing date on grain yield, yield components and percentage of protein in green gram cultivars. [Persian] Iranian J. Agri. Sci., 29(4): 751-758.

Thavaprakash, N., Jagannatham, R., Velayudham, $\mathrm{K}$ and Gurusamy, L. (2007). Seasonal influence on phenology and accumulated heat units in relation to yield of baby corn. Inter. J. Agric. Res., 2(9): 826-831.

\section{How to cite this article:}

Bankar, D.S., S.B. Pawar and Kadam, Y.E. 2018. Thermal Utilization and Heat Use Efficiency of Green Gram Varieties under Different Sowing Dates. Int.J.Curr.Microbiol.App.Sci. 7(10): 2270-2276. doi: https://doi.org/10.20546/ijcmas.2018.710.262 